\title{
The Satirical Tradition of Collodi and Pinocchio's Nose
}

\begin{abstract}
This paper explores the theme of Pinocchio's nose in Carlo Collodi's The Adventures of Pinocchio (1883) and its retellings, with particular emphasis on the satirical aspects of the texts. Collodi's Pinocchio is known as a children's story, yet it is a text written for both children and adults, and is entertaining for both due to its satirical and subversive nature. Both in terms of stylistics and visual references, Collodi was influenced by Laurence Sterne's satirical texts, in particular by The Life and Opinions of Tristram Shandy, Gentleman, published more than a century earlier. Sterne's influence is clearly manifested in the case of Pinocchio's growing nose. The article explores how this theme has been used satirically in postmodern retellings of Collodi's text, such as Jerome Charyn's Pinocchio's Nose (1983) and Robert Coover's Pinocchio in Venice (1991). Even though Pinocchio's growing nose is frequently associated with lying, the focus of this article will be on Freudian interpretations and sexual allusions, and how satire works in that context.
\end{abstract}

Keywords: Carlo Collodi, Jerome Charyn, Laurence Sterne, noses, Pinocchio, Robert Coover

This article will present the satirical elements in The Adventures of Pinocchio, in particular with regards to Pinocchio's nose, and examine the historical context of its author, Carlo Collodi, as well as influences on him, such as Laurence Sterne. It will also show how Collodi's satirical tradition continues in contemporary retellings of his work, such as Robert Coover's Pinocchio in Venice and Jerome Charyn's Pinocchio's Nose.

Carlo Collodi's Le avventure di Pinocchio: Storia di un burattino (henceforth referred to by its English title, The Adventures of Pinocchio) is one of the most famous texts in the world and the "most translated non-religious book in the world" (Rollino 2014). ${ }^{1}$ The Adventures of Pinocchio tells the story of an animate puppet carved by Geppetto from a talking log. Pinocchio is a puppet-boy who is supposed to go to school, but he is sidetracked by the Fox and the Cat, who deceive and almost kill him. He is saved by the Blue Fairy, but he has more adven-

1 All translations in this article are my own unless otherwise indicated.

Ә Open Access. (c) 2021 Georgia Panteli, published by De Gruyter. (c) BY-NC-ND This work is licensed under the Creative Commons Attribution-NonCommercial-NoDerivatives 4.0 International License. https://doi.org/10.1515/9783110642032-030 
tures, in which he faces enemies and is helped by friends and by the Fairy, until he is finally transformed into a human boy with her help and reunited with his father, Geppetto. The story has been given many characterizations, from rite-ofpassage novel to Bildungsroman and picaresque novel. ${ }^{2}$ It originated as a series of stories for the children's magazine Giornale per i bambini, and due to its great success it grew from an initial fifteen to thirty-six chapters.

Numerous "Pinocchiate" have been written, both as critical analyses and as retellings of Collodi's text. Many of them focus on the mystery of Pinocchio's growing nose. The story of the puppet who wants to become a real boy is mostly known through its Disney adaptation, which has discarded all the satirical elements and nuances of the original text, such as the playfulness of Pinocchio's growing nose. Collodi was writing for two audiences, for both children and their parents. Even though lying is widely known as the reason for the growth of Pinocchio's nose, this was not originally the case.

What Collodi had originally planned to be the story of Pinocchio would have ended with chapter 15, when Pinocchio is hanged from the Great Oak and dies; the theme of telling lies had not been associated with Pinocchio's growing nose at this stage. Up until this point, there are only two occasions when Pinocchio's nose grows, and neither of them is associated with lying. The first one is when Geppetto carves him into being, and the second is when he is frustrated by the optical illusion of a painted kettle while being very hungry. On both occasions, his nose grows, but not out of proportion. In fact, there is an instance in chapter 7 when Pinocchio tells a lie (that the cat ate his feet) but his nose does not grow.

Collodi's young readers insisted that the story continue, and the magazine's editor, convinced by the possibilities for profit, asked Collodi to keep writing. Collodi revived the dead puppet, expanding on themes that he had already introduced in the first part of the story, that is, Pinocchio's disobedience and his growing nose - and thus lying was invented as part of Pinocchio's naughty and disobedient character. When Pinocchio has his first proper encounter with a female character, his nose grows disproportionately for the first time in the narrative.

The sexual reference to the male member in Pinocchio's elongating nose is an allusion that Collodi purposefully and satirically included in his picaresque coming-of-age tale. It is the story of an adolescent boy who, for the first time, encounters a woman. This is consistent with Pinocchio's character throughout the text: it is during adolescence that children become more restless and independent from their parents; they are eager to try things on their own and are fre-

2 See Apostolidès (1988); Eco (2009); Morrissey and Wunderlich (1983). 
quently overconfident, misjudging or ignoring potential dangers, as Pinocchio does throughout the book. Pinocchio therefore exhibits the easily recognizable behaviour of a prepubescent boy.

We can assume that the sexual connotation of the nose was clear to Collodi for numerous reasons. First of all, the attribution of character traits to physiognomic characteristics was very popular during the eighteenth and nineteenth centuries, and there were extensive theories about which part of a person's physical appearance corresponded to which trait. The nose has also been a metonym for the penis for many centuries. Giambattista della Porta, for instance, wrote an encyclopedia on physiognomy in 1586 that was translated into Italian from Latin as Della fisionomia dell'huomo in 1644. He writes that the nose corresponds to the penis and the nostrils to the testicles. ${ }^{3}$ This assumption dates back to Ovid, who had the nickname "Naso." Sander Gilman comments as follows: "It was not merely that in turn-of-the-century Europe there was an association between the genitalia and the nose; there was, and had long been, a direct relationship drawn in popular and medical thought between the size of the nose and that of the penis. Ovid wrote: 'Noscitur e naso quanta sit hast viro"' (Gilman 1991, 188). However, Don Harrán (2013, 59n26) mentions that these words, although popularly attributed to Ovid because of his nickname, cannot be traced to his writings. Regardless of the phrase's origins, what is interesting here is that Collodi could have been exposed to such information and therefore that his puppet with the big nose and its numerous transformations could be an indirect tribute to Ovidius "Naso" and his Metamorphoses. It is, in fact, almost impossible for Collodi not to have been exposed to such details, including physiognomy and popular references, as the nose was one of his interests as an author: one year before the publication of Pinocchio, he published a collection of stories called Occhi e nasi [Eyes and Noses] (1891).

Collodi was very conscious of linguistic idioms and the expressions he used, for he had written books for educational purposes before. In the second part of Pinocchio, he uses two Italian proverbs and explores them visually through Pinocchio's story. This indicates both an instructive and also a playful approach to language. When Pinocchio lies to the Fairy and his nose grows out of proportion, she tells him: "Lies, my dear boy, are quickly discovered; because there are two

3 "E degno d'annotarsi esser proportione tra le parti della faccia con quelle di tutto il corpo, e da loro vicendeuolmente si corrispondono, ò nella misura, ò nella quantità, ò ne’ tempi. Il naso risponde alla verga, che havendo alcuno lungo, e grosso, outro acuto \& gioffo, ò breve, il medesimo si giudica di lui, così le nari rispondono a i testicoli. Nasuti apresso Lampridio si dicono quelli, che più maschi sono" (della Porta 1644, 2: 83). 
kinds. There are lies with short legs, and lies with long noses. Yours is clearly of the long-nosed variety" (Collodi 1986 [1883], 211). This refers to two proverbs associated with lying. Both proverbs are mentioned in the Dizionario delle origini, an Italian dictionary of 1828; they were therefore already in use during Collodi's time. The first one is Le bugie hanno le gambe corte "Lies have short legs." Even though this metaphorically means that someone cannot go too far when lying or they will be discovered, it is alluded to visually when Pinocchio's feet are burnt in the first part of the story. The other proverb is La bugia corre su pel naso "The lie runs on the nose." ${ }^{5}$ The Dizionario explains that this expression refers to the blushing that occurs when someone is lying. Blushing occurs on other occasions as well, as for example when caused by shame or sexual arousal. The nose is a visual reference already present in the first part of the story, as mentioned earlier. Collodi chooses the imagery of the growing nose to continue the story, as it offers amusing elements that his young readers would enjoy and sexual connotations that would tickle his older audiences.

Furthermore, it was common in Collodi's time to attribute sexual connotations to the nose in literature. A characteristic example is Laurence Sterne's The Life and Opinions of Tristram Shandy, Gentleman. The theme of the protagonist's nose in relation to his penis was portrayed in illustrations and covers for the book, the most famous being that of the Dutch translation of 1771. Sterne was translated into Italian during Collodi's time (Sterne 1831). It is very likely that Collodi had access to such material, as is apparent from Sterne's influence on Collodi's style. Daniela Marcheschi (1995, xxii) remarks in this respect: “Collodi's humour displays the general influence of Sterne's parodic, ironic, and satirical style, not excluding the playful malice of sexual innuendos." It is very likely that Collodi was familiar with these connotations, especially since he had written about noses before and would have researched relevant material.

The frequent double entendres and sexual innuendos in Tristram Shandy seem to have had a great influence on Collodi's style. In the third book of The Life and Opinions of Tristram Shandy, the protagonist's father narrates a nose-related story from a book by the fictional nose expert Hafen Slawkenbergius (the scatological reference for the German-speakers among his readers adds to the satire - Hafen "chamber pot," Schlackenberg "mountain of excrement"). The story follows Don Diego, who causes unprecedented turmoil in Strasbourg because of his unusually and exceptionally long nose. Sterne had earlier declared: "By the word Nose, throughout all this long chapter of noses, and in every other part of

4 See Dizionario (1828, 1: 469).

5 See Dizionario (1828, 1: 469). 
my work, where the word Nose occurs, - I declare, by that word I mean a Nose, and nothing more, or less" (Sterne 1997 [1759-1767], 173-174). Despite this earlier declaration, the story is loaded with sexual connotations and allusions. Everyone in the city of Strasbourg longs for Don Diego's nose, including nuns, widows, and married women, old and young, as well as men, who lose their sleep and their peace of mind over theories about and longing for the protagonist's nose. Sterne's satire and irony is sharp in the way the narration unfolds in a completely anticlimactic way: the reader never finds out why Don Diego had such a long nose and what happened to him, and no sexual act takes place in the end. Sterne thereby subverts readers' expectations and playfully suggests that such thoughts are temptations and suggestions of the Devil.

Since Collodi was also writing for children, the sexual connotations of Pinocchio's nose are somewhat implicit, but clearer for his adult readers. Sterne's postmodernist style of subverting readers' expectations, however, is present in other parts of Collodi's Pinocchio (such as its first lines). ${ }^{6}$

Collodi's satire, frequent and playful throughout the text, manifests itself as a nuance when it comes to Pinocchio's nose. However, in recent retellings of Collodi's text, such as Jerome Charyn's Pinocchio's Nose (1983) and Robert Coover's Pinocchio in Venice (1991), the growing nose of Pinocchio as a sexual metaphor is used extensively.

Pinocchio's Nose is the story of Jerome Copernicus Charyn, a Jewish-American author who grows up in the Bronx during the 1940s. Struggling to balance his writing and teaching careers, and trying to overcome his troubled relationship with his mother, he escapes into the world of his novel, Pinocchio 1945, by entering Pinocchio's wooden body and thus becoming the protagonist he invents: Pinocchio in Mussolini's Italy. Pinocchio in Venice is the story of Professor Pinenut, who is Collodi's centenarian Pinocchio, having grown up after his magical transformation into a boy and become an emeritus professor at a US university and a two-times Nobel laureate. He returns to Italy in order to write "Mamma," the last chapter of his autobiography. As soon as he arrives in Venice, he goes through a series of adventures, meeting old friends and enemies, until he finally meets the Blue Fairy, his inspiration and tormentor, in her true form.

Robert Coover's retelling of Pinocchio is a metafictional masterpiece, paying tribute to Collodi's satiric style but also to that of his sources of inspiration, and in particular to Sterne. Coover places the origins of Pinocchio's desire for humanity

6 One example of this is "Once upon a time there was - 'A king!' my little readers will say at once. No, my dears, you are wrong. Once upon a time there was a stick of wood” (Collodi 1986 [1983], 83; see Patten 1983, 72). 
in a particular scene in Collodi's text: in chapter 15 of The Adventures of Pinocchio, Pinocchio is on the island of the Busy Bees and has just found out that the Little Girl with blue hair has not died, as was written on a gravestone near her house. The Fairy has instead been transformed into a woman, the lady he helped with carrying water. Pinocchio is bewildered by her change:

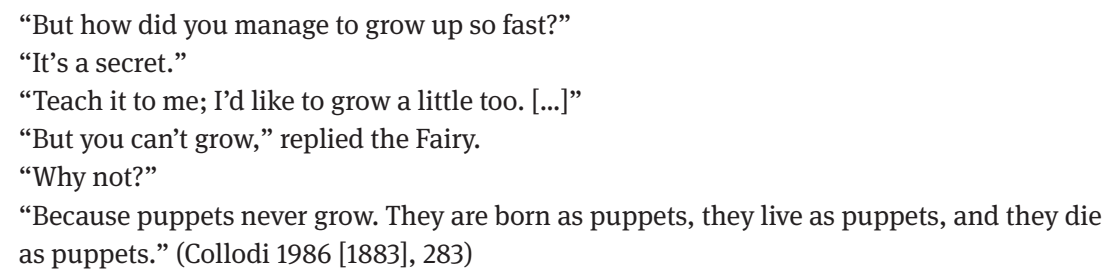

At this moment, Pinocchio realizes how different he is. Even though he looks like a puppet, he has always behaved like any other child, and this is how everyone has treated him so far - as just another disobedient child. This is the first time he hears from someone he trusts that he is not like everyone else. His immediate reaction is to reject his condition and desire change: "Oh, I'm sick and tired of always being a puppet! [...] It’s about time that I too became a man” (Collodi 1986 [1883], 283).

Coover's interpretation elaborates this scene in a specific direction. He explores why Pinocchio would want to become like the Fairy. This question is answered in Pinenut's narration of his past: "When he recognised her, he knelt and hugged her knees, and she gave him a glimpse of a possible future, more than one: he had to choose" (Coover 1991, 72). It is a sexual motivation that drives the early, prepubescent Pinocchio to desire humanity. This moment is what he reminisces upon during a cold winter night in Venice when he thinks he might be dying: "but all that comes to him there under his helmet of iced scarf is what he saw that awesome day when she spread her knees as though to reveal to him his fate" (Coover 1991, 46). The fate he chose, of course, was that of becoming human, as instructed by the Fairy.

Coover uses as a starting point Collodi's implicit reference to Pinocchio's nose as a penis which is elongated out of proportion when he first encounters a woman, the Blue Fairy. Coover expands on that to mock the quasi-religious value that has been attributed to Pinocchio's desire for humanity by exposing it as an adolescent's emerging (and therefore also scary) sexual drive. The following excerpt refers to when Pinocchio lands on the Island of the Busy Bees and finds the Fairy again; she is not the little girl he knew and has now grown into a woman. This is Coover's version: 
He'd been cast up by a storm and was begging at the edge of town when she found him. She offered him a supper of bread, cauliflower, and liquor-filled sweets in exchange for carrying a jug of water home for her. He'd last seen her as a little girl, and moreover presumed her dead, so he didn't recognize this woman, old enough to be his mother, until she took her shawl off and he saw her blue hair. Whereupon he threw himself at her feet and, sobbing uncontrollably, hugged her knees. “Oh, why can’t we go home again, Fairy?” he wept. "Why can’t we go back to the little white house in the woods?” Her knees spread a bit in his impassioned embrace, and the fragrant warmth between them drew him in under her skirts. He wasn't sure he should be in here, but in his simple puppetish way he thought perhaps she didn't notice. He felt terribly sleepy, and yet terribly awake, his eyes open but filled with tears. (Coover 1991, 116)

So far, this remains true to Collodi's original, even if spiced up with Coover's details. However, the following part of the encounter scene reflects Coover's Freudian approach and added interpretation:

\begin{abstract}
"Let me tell you a story, my little illiterate woodenknob," she said above his tented head, "about the pretty little white house and the nasty little brown house - do you see them there?"7 He rubbed his eyes and running nose against her stocking tops and peered blearily down her long white thighs. Yes, there was the dense blue forest, there the valley, and there (he drew closer) the little house, just hidden away, more pink than white really, and gleaming like alabaster. But the other -? "A little lower ...” She pushed on his head, sinking him deeper between the thighs, until he saw it: dark and primitive, more like a cave than a house, a dank and airless place ringed about by indigo weeds, dreary as a tomb. She pushed his nose in it. "That is the house of laziness and disobedience and vagrancy," she said. "Little boys who don't go to school and so can only follow their noses come here, thinking it's the circus, and disappear forever." He was suffocating and thought he might be disappearing, too. She let him out but, even as he gasped for breath, stuffed his nose into the little white house: "And here is the house for good little boys who study and work hard and do as they are told. Here, life is rosy and sweet, and they can play in the garden and come and go as they please. Isn't that much better?"

"Yes, Mamma!" he said, and it was better, but he was still having trouble breathing. He tried to back out but he was clamped in her thighs. (Coover 1991, 116-117; emphasis in original)
\end{abstract}

Coover interprets the Fairy's doctrine as one of a heteronormative society that demands its members to be functional and rewards production with reproduction, as shown by the reward she promises him if he works hard: the little white house, a metaphor for the vagina. He can have access to it and reproduce only as a hard-working man and not as a puppet. The scene of re-encountering the Fairy, portrayed as a sexual encounter, is what instils in Pinocchio the desire for humanity and defines his relationship to her as one of obedience and reward. Professor

7 In Collodi's text, the Blue Fairy lives in a little white house in the middle of the forest. 
Pinenut tries to live by the Fairy's rules all his life, and this is what seems to be the cause of the illness that turns him back to wood.

Coover's satire is abundant throughout the book: from his constant and excessive reference to experts, real and fictional (a characteristic of Sterne's satire as well), to the infantile obsession of Professor Pinenut with his much younger student and his running after her in the streets of Venice, he mocks academia repeatedly. Pinenut's sexual desire for the Fairy is the driving force behind his decisions and, like a neurosis caused by his Oedipal complex, it follows him in every step of his life. In the end, that complex is resolved as he succumbs to the Fairy's true nature and she fulfils his Oedipal desires. It is resolved through annihilation, though, as Pinenut asks her to undo her magic in return, as if he had never been transformed into a human. His desire for becoming human was triggered by his desire for her, and since they can be united anyway without that condition having to be met, humanity is not necessary for Coover's Pinocchio.

Charyn's Pinocchio, on the other hand, does not resolve his Oedipal complex that easily. His neurosis is stronger, for the main representation of the Blue Fairy in Pinocchio's Nose is his real mother, Bathsheba. As Robert L. Patten suggests, he suffers from a “chronic Oedipal crisis” $(1983,68)$. The use of Pinocchio's nose as penis is only explored in the parallel story where Jerome inhabits Pinocchio's body. Brunhilde, the prostitute who is also Pinocchio's substitute mother, teaches him the function of his nose after she discovers that he has no genitals. She finds out that the sexual function of a penis has been transferred to his nose instead, so she teaches him how to "tickle" (Charyn 1983, 84) her with it. Even though Jerome fulfils his Oedipal fantasies through Brunhilde, it is however Bathsheba's attention, which he has never succeeded in earning, and her neglect that haunt him throughout his life. It is because of her that he invents the story of Pinocchio - the fictional space he disappears into in order to escape from his upsetting reality.

Throughout Charyn's novel, the Blue Fairy appears in the form of different women, but there is always an emphasis on her unkind and dark nature, which was already hinted at in Collodi. Jerome's mother is the main representation of the Fairy, but also of every other woman that has a strong impact on him. To make that even more explicit, there are numerous references to the colour blue when the author refers to his mother or to other women who have a very strong influence on him. His disturbed relationship with Bathsheba is made explicit by the way he dreams of her: "And I had dreams of stuffing Bathsheba's mouth with strands of blue hair. Because I'm sure my mother used to bribe me with her milk. When I was bad, she took me off the tit" (Charyn 1983, 40). In his dream, he stuffs hair into his mother's mouth, an act that can be interpreted as violent but also as sexual, as "stuffing the mouth" could be a suppressed metaphor for the sexual act. Everything is subverted and opposed to its original meaning. Similarly, his 
mother's milk, a symbol of life and of the strong bond between the child and the mother-nurturer is presented as a means of punishment and bribery. In another instance, Jerome even presents it as lethal: "What did I care if the devil wrote Ulysses? The music in that novel was like my mother's milk. Something deadly and accurate, that could lull a boy to sleep" (Charyn 1983, 48).

In Montegrumo, where the fictional Pinocchio of the parallel story is born, the Blue Fairy is Brunhilde, the prostitute of the village, who is trusted by Geppetto after he turns her into a socialist. After she dies, her ghost comes back and haunts Pinocchio in the form of his fairy godmother. She is referred to as the Blue Fairy directly and not implicitly. It is no coincidence that Brunhilde takes the Fairy's role, for she is the woman that Geppetto chose as Pinocchio's mother. In the fictional world, Jerome realizes his suppressed fantasies, for Brunhilde, his "mother," is the one who initiates him into discovering the sexual nature of his nose. Brunhilde also fails in her maternal role, just as Bathsheba apparently failed with Jerome.

Charyn's novel, rich in playful satire and irony, mocks the publishing industry, both through the character of Marvela Ming, doyenne of the New York Review of Books and one of the Blue Fairy's reincarnations, and with the entire self-referential concept of writing and escaping into one's novel. The extended emphasis on the sexual references to Pinocchio's nose is an additional mockery of the Freudian and psychoanalytic interpretations that were quite fashionable at the time.

Collodi's nuanced satire resonates strongly in Charyn's and Coover's metafictional novels, as the theme of the nose as sexual metaphor illustrates. As I have explained in my analysis, there were numerous references to the nose as penis in Collodi's time, of which Laurence Sterne is a major example. Although Collodi only implicitly makes such references, it is evident that he intended to entertain the adults among his audience with puns and sexual allusions. I have illustrated the ways in which Collodi used the theme of Pinocchio's nose as sexual metaphor and demonstrated how he created a tradition of satire as seen in the retellings of Coover and Charyn. I have also demonstrated how Collodi's text functions like a bridge in linking his influences, such as Laurence Sterne, with authors who followed his tradition by retelling his seminal novel. All four texts are connected through their intertextual references and satirical elements, and Collodi's Pinocchio is the literary glue that keeps them together in a metafictional embrace. 


\section{Works cited}

Apostolidès, Jean-Marie. “Pinocchio, or A Masculine Upbringing.” Merveilles \& Contes 2.2 (1988): 75-85.

Charyn, Jerome. Pinocchio's Nose. New York: Arbor House, 1983.

Collodi, Carlo. The Adventures of Pinocchio. Trans. Nicolas Perella. Berkeley and London: University of California Press, 1986. Trans. of Le avventure di Pinocchio: Storia di un burattino. Florence: Felice Paggi, 1883.

Collodi, Carlo. Occhi e nasi: Ricordi dal vero. Florence: R. Bemporad e Figlio, 1891.

Coover, Robert. Pinocchio in Venice. New York: Linden Press; Simon and Schuster, 1991. Della Porta, Giambattista. Della fisionomia dell'huomo. Vol. 2. Venice: C. Tomasini, 1644. Dizionario delle origini invenzioni e scoperte nelle arti, nelle scienze, nella geografia, nel commercio, nell'agricoltura. Vol. 1. Milan: A. Bonfanti, 1828. https://bit.ly/2PQQWNh (29 August 2018).

Eco, Umberto. "Introduction.” Pinocchio: The Tale of a Puppet. By Carlo Collodi. Trans. Geoffrey Brock. New York: New York Review, 2009. ix-xi.

Gilman, Sander. “The Jewish Nose.” The Jew’s Body. By Gilman. New York: Routledge, 1991. 169-193.

Harrán, Don. "The Jewish Nose in Early Modern Art and Music." Renaissance Studies 28.1 (2013): 55-70.

Marcheschi, Daniela. "Introduzione.” Opere. By Carlo Collodi. Ed Marcheschi. Milan: Mondadori, 1995. ix-lxii.

Morrissey, Thomas J., and R. Wunderlich. "Death and Rebirth in Pinocchio." Children's Literature 11 (1983): 64-75.

Patten, Robert L. "Pinocchio through the Looking Glass: Jerome Charyn's Portrait of the Artist as a Mytholept." NOVEL: A Forum on Fiction 17.1 (1983): 67-76.

Rollino, Massimo. "Presentazione." Pinocchio Svelato: I luoghi, il bestiario e le curiosità nella favola del Collodi. By Giuseppe Garbarino. Florence: AB Edizioni, 2014. 5.

Sterne, Laurence. Saggio di sermoni sacri. Milan: F. Stella, 1831

Sterne, Laurence. The Life and Opinions of Tristram Shandy. 1759-1767. London: Penguin 1997.

Dr Georgia Panteli completed her PhD in Comparative Literature at UCL with a thesis entitled "Postmodern and Posthuman Retellings of the Pinocchio Myth." Her book From Puppet to Cyborg: Pinocchio's Posthuman Journey will be published by Legenda in 2021. Her research interests include fairy-tale retellings, cyborg and cyberpunk literature, graphic novels, posthumanism, and metafiction. She teaches film at the University of Vienna. 